\title{
Between a Rock and a Hard Place: Corporate elites in the context of religion and secularism in Turkey
}

\begin{abstract}
Drawing on discourse analyses of 36 in-depth interviews with elite business people from Turkey, the study identifies the networking patterns of new and established business elites in the context of economic liberalization and socio-religious transformation of the country. Through a comparative analysis of the so-called secular and religious elite networks, we demonstrate the role of institutional actors such as the government, and identity networks, based on religion and place of birth in shaping the form and content of social networks among business elites in Turkey. In order to achieve this, we operationalise Bourdieu's notion of theory of practice and Granovetter's theory of social networks, illustrating the utility of combing these approaches in explicating the form and content of social networks in their situated contexts, in which power and divergent interests are negotiated.
\end{abstract}

Keywords: Business elites, Turkey, social network, social capital, cultural capital, businesspeople association

\section{Introduction}

Studies on business elites seem to have attracted limited attention in spite of the calls by prominent authors (see Pettigrew, 1992; Whittington, 2004; Savage and Williams, 2008; Zald and Lounsbury, 2010). Whittington (2004:62) stresses the need for a sociological agenda interested in "understanding strategy's elites" since their actions may have important 
repercussions for society. Drawing on a field study with in-depth interviews, we identify the liberal policies and conservative forces prevailing in the Turkish context on business networks of the corporate elites. The adoption of liberalization policy in 1980 and Islamic tendencies increasingly surfacing in the same period makes Turkish business milieu a valuable setting in which to investigate the impact of the context on corporate elite's business networks. Businesspeople ${ }^{1,} \mathrm{~s}$ associations together with their respective ideologies and member profiles are investigated in a way to assess the interplay of their form and substance with the changing conditions, primarily borne out of the liberalization of economic policies and an increased emphasis on religion.

Two divergent approaches are evident in theorization of social networks in their situated setting. First, Granovetter's theory of social networks explains that human relations, is not conjugated only in terms of instrumental rationality, but also of sociability, approval, status and power (Granovetter, 1985). Second, Bourdieu's theory of practice illustrates the relative stability of capitals, choices and chances of individuals and networks across fields of relations (Authors, 2006). Combined together Granovetter and Bourdieu's theoretical approaches promise to capture the coexistence of dynamism and stability, in other words, change and continuity, in social networks (Authors, 2012). This study identifies the networking patterns of new and established business elites in the context of economic liberalization and socioreligious transformation of the country. Through a comparative analysis of the so-called secular and religious elite networks, we demonstrate the significance of context in understanding social networks as sites, where power and interests are negotiated. Developing Granovetter's theory of social networks, we mobilise concepts from Bourdieusian sociology

\footnotetext{
${ }^{1}$ The original title of these associations can be translated as "Businessmen" associations. However, all of them have female member as well. For this reason, throughout the paper, we preferred to use the term "Businesspeople"
} 
and demonstrate the significant role of institutional actors such as the government, and identity formations, based on religion or place in shaping the form and content of social networks among business elites in Turkey.

Instead of emphasizing the affective features of the human action which is constructed upon similarities and familiarities engendering trust in human relationships, Granovetter initially stressed that action develops rather in a network of seemingly less-affective ties, namely weak ties, that the use by actors results in a type of relationship involving greater number of individuals (Granovetter, 1973: 1369). He also argues that not every weak tie but rather, the ties capable to establish direct and unique links between unconnected actors (bridges) have the capacity to shape an effective relationship (Granovetter, 1985: 208). Bourdieu's theory of practice and the field illustrates, however, that an individual's endowment of symbolic and material resources, i.e. different forms of capital, render their actions predictable among a milieu of actors.

Although the emergence and development of business networks in Turkey, have some divergent aspects vis-à-vis Granovetter's weak ties approach, the crucial role played by bridges in a network of business relationships seems to display similarities. Instead of communal relationships based on proximity, familiarity, traditionally-determined trust systems, newly emerging networks of businesspeople offer to their adherents a quite different type of cooperation in Turkey. Although they seem to have implicit yet ideologically-driven qualities, such as religious orientation, conservatism, protectionism, secular and modern conception of the world, in their formation, they, in fact, tend to form a new kind of ad hoc entity to resist the pressures and necessities of the globalization. Drawing on Bourdieu, it is 
possible to explicate how with new elites emerge a new set of rules, forms and substantial network relationships. While Granovetter accounts for the dynamism in networks, Bourdieu's approach allows us to present dynamism in the context of stability in the broad field of relations.

Biggart and Delbridge (2004) with their typology of exchange systems, point out an alternative perspective. By a distinction between price system (universalistic instrumental rationality), associative system (particularistic instrumental rationality), moral system (universalistic substantive rationality) and communal system (particularistic substantive rationality), they classify major forms of exchange based on the openness level of the group towards outsiders (universalistic/particularistic) and their relation with the instrumental logic (direction of the calculus between means and ends). Most Turkish business associations seem to be characterized by a blend of moral and communal systems. Especially the newly rising ones appear to prioritize the in-group harmony through an apparent ideological or moral motivation, paving the way to integration with a global price system.

Granovetter (1983) has further developed his initial theoretical model with other empirical data, which confirm that weak ties in inter firm relationships facilitate the creation of cooperation and coordination in the national network of economic actors. Capitals of Bourdieu (1979) are utilized to assess characteristics of network members as well as their actions towards domination. Drawing on Bourdieu's theory we show the importance of social capital as well as economic and cultural capitals in shaping the context of Turkish business elites. Our analysis on the formation, structure and functionality of the business associations in Turkey reveal both an articulation with the network-basis perspectives, especially the one 
developed by Granovetter, and a reevaluation and a micro-adaptation of the Bourdieu's notion of capitals in today's changing Turkish business world.

Burt (2005) proposes in his both challenging and complementing approach to Granovetter, a consideration of a relatively under-estimated aspect of network system and focuses on "structural holes". He accentuates the contribution of the network relationships to the enrichment of the social capital. According to Burt, a network rich of holes (unconnected persons or clusters of relationship) is more promising than that paved of familiar connections, because relatedness depends on the communicative capacity offered by the discontinuous network. Unknown, unexplored identities and beliefs can be an effective source to multiply the social capital (Burt, 2005: 17). On the other hand, Townley (2002:561) criticizes the taken-for-granted characteristic of the modernist rationalistic and mechanical models that try to analyze the macro-structures, but often under-estimate the importance of the "microphysics of power". Instead, she proposes a notion of organization which is complex, interactive and dynamic, consisting of multiple and complex interactions and circular causality. In fact, in this study we draw attention to power and domination within and around the businesspeople networks in Turkey.

Lounsbury and Ventresca (2003) claim that Bourdieu's approach to the conception of capital and consequently to the meaning of social relationships instigated the rise of a new structuralism in management studies. This approach emphasizes the comprehension of the connection between intraorganizational networks and broader societal dynamics that influence the prospects for voice in specific surroundings. The impact of Bourdieu's theory on the production of domination through social capital has thus interwoven a wide range of critical reflections in the management and organization studies. 
Drawing on Bourdieu allows us to re-theorize context as a significant aspect of network relationships: Political context, in particular the interplay of religion, state, trade unions, employers are ignored in the network theory, which assumes that context is fixed, and not relevant to such theorization. In the European setting, we need to consider context more keenly as the institutional differences are often outcome of unique historical paths. For example, in their review of diversity management field, Authors (2011) identify that discourses and practices in this field of management are shaped by both macro-economic forces of liberalization, and social changes such as decline of social solidarity and surge of individualism. They also demonstrate that institutional actors such as trade unions, employers unions, professional bodies, universities and consulting businesses play important roles in negotiating the form and structure of the field. They use the Bourdieusian concept of the field in order to bring a macro-economic and social dimension to our understanding of social networks. The concept of the field allows us to bring in history, place and relationship among actors in order to understand how certain practices and network ties are maintained.

By exploring multiple actors and their positions, we are also able to reveal relationships of power in its situated emic context if we use Bourdieusian concept of the field. Therefore in this study, we bring an assessment of power and context in order to develop social network theory by adding it a macro-context. We believe that this is important in understanding contexts, such as Turkey, which fall outside the traditional imagination of western theorization. Assessing history and place in reading social networks can help us draw an emic understanding of relevant processes, freeing our theorization from etic Western concepts of social network formation, the transposition of which may not be so suitable in the case of Turkey. We believe that the absence of macro perspective in social network theorization is 
also problematic at the source of much social network theorization. In fact, providing macro context in western theorization can delineate fine distinctions between countries and histories which shape our understanding of social networks in the western world, which is not a monolithic, uniform entity.

\section{Contextual assessment of Turkey in the process of economic liberalization and socio- religious transformation}

Turkey is a country of civil law and its legal system contributes to the central role of the state in the Turkish business system (Authors, 2012). Consistent with the predictions of the Legal Origins theory, the economy is mostly guided by state desired allocations rather than market based outcomes (La Porta et al., 2008). Turkish business context is typically characterized by the family-controlled, diversified big business groups (Guillén, 2001) whose development was encouraged by the state. The state formed partnerships with these businesses, provided credits from state banks and low cost inputs, and protected them from foreign competition (Buğra, 1994). The intricate nature of the relationship between the state and the business firms necessitates a careful handling of this link and enforces owning families to take part in the management of their companies (Buğra, 1994).

These basic characteristics of the business system in Turkey continue in spite of the major macroeconomic policy shifts. Turkish economic policy reached a breaking point in the beginning of 1980. The preceding decade was subject to high inflation rate coupled with the erratic regulatory regimes caused by political instability which made high levels of uncertainty the basic characteristic of doing business in Turkey (Yurtoglu, 2004). Abandoning import substitution policy that has been focusing on the domestic market, a trade 
liberalization program based on export promotion was launched in the early 1980s (Yurtoglu, 2000). Turkey was to adapt herself to the realities and requisites of the global economy and the globalization process, which demanded a "restructuration" of the national economy. Therefore, the system of mixed economy was abandoned, state economic enterprises were privatized, and a series of neo-liberal policies were launched in order to quit the existing "nationalist development model" in favor of the transition to global capitalism (Türe, 2008: 89).

As a consequence several initiatives were taken. In 1986, Istanbul Stock Exchange was founded. The economic liberalization also brought in notions such as human resource strategies to the Turkish business context (Ercek, 2006; Kaya, 2006; Kaya et.al, 2010; Collings et.al, 2010; Kusku and Ataman, 2011; Gurbuz and Mert, 2011) With these large scale reforms supported also by the majority of the economic elites, the control on foreign currency was abandoned, the value of the Turkish Lira was determined by the market, foreign capital entry controls was suppressed and attempts to develop capital from Islamic, especially Arab countries were made (Öniş, 2004). The same period was also characterized by an attempt to combine Islamic identity with liberal economy (Lacinok, 2007). This tendency further enforced by the victory of pro-Islamist parties in 1990s and 2000s. Particularly, the pro-Islamist AKP that have been governing since 2002 promised to respect integrally the neo-liberal economic policies deployed since the 1980s.

The Anatolian conservative entrepreneurs, weary of AKP's predecessor's politically risky discourses (pro-Islamic parties have already been banned several times by the Constitutional Court, on grounds of anti-secular activities destined to install an Islamic regime) needed a 
political organization which allied Islamic belief with pragmatism, but gave priority to private enterprise, free market, competition and profits (Kumbaracıbaşı, 2009).

Following the liberalization, the industrial production, primarily limited to Istanbul and Marmara region became scattered throughout Anatolia, thanks to the proliferation of export oriented small and medium size enterprises operating in various industrial zones that reflected the dynamism of the ambitious entrepreneurs passing from local to global markets, even without transiting by the national one (Keyman, and Lorasdağı, 2010). This proliferation was also stimulated by the large businesses of the Marmara region, which outsourced part of their production to the Anatolian companies (Buğra and Savaşkan, 2010) while competing in international markets.

Transition to liberal economy and the attempts to combine Islamic identity with liberal economy influenced considerably business networks. A proliferation of the businesspeople associations with a religious accent characterized the period following the economic and social transformation. The new Anatolian conservative economic and political elites who once felt that they were socially and culturally "excluded" savored their common triumph, and displayed openly their interests in securing their proper seats among the established elites. The religiously conservative entrepreneur groups, not only those dwelling in Anatolian cities but also those operating in Istanbul and Marmara region were also willing to improve their social networks. As an alternative to the "Turkish Association of Industrialists and Businesspeople” (TUSIAD-Türkiye Sanayici ve İşadamları Derneği) founded in the 1971 by the modernist established economic elites of the Istanbul area, the Anatolian entrepreneurs, close to then leading pro-Islamist Welfare Party (RP), created in 1990, MUSIAD (Müstakil Sanayici ve İşadamları Derneği) "The Association of Independent 
Industrialists and Businesspeople" (Pamuk, 2008). The first three letters of the denomination of "Müstakil" meaning independent could also be read as "Muslim". While TUSIAD's membership size is relatively small and composed of large firms mainly located in Istanbul and surrounding areas, MUSIAD's membership size is larger and geographically spread and mainly composed of SMEs (Öniş and Türem, 2001). However, TUSIAD's members manufacture 65 percent of total industrial production and their share in total exports is about 85 percent (Buğra and Savaşkan, 2010). MUSIAD has close ties with the pro-Islamist parties and intends to play a pressure group role in favor of its members at governmental spheres (Buğra and Savaşkan, 2010).

Another business network "The Confederation of Turkish Businesspeople and Industrialists" (TUSKON), that shelters religiously conservative entrepreneurs was founded in 2005 (Sönmez, 2010). But its founders and members mostly belong to Fethullah Gülen's religious community, and keep a certain distance with MUSIAD (Buğra and Savaşkan, 2010). Gülen maintains a "concept of the secular world as "dar-ul hizmet" (the abode of service to mankind), which he substitutes for the traditional notion of "dar-ul harb" (the abode of war against infidels) (Mango, 2006). This perspective is similar to the basic tenet of other religiously inspired business networks, such as the Opus Dei, for the members of which all work should be performed as divine service" (Mango, 2006). In TUSKON Islamic references are kept in second plan while nationalist discourses are deployed: Islam is characterized as an important element of Turkish nationalism (Buğra and Savaşkan. 2010: 104). TUSKON especially provides network for local SME's willing to reach to foreign markets and find also raw materials for their productions. The impressive educational institutions created by Gülen's followers in five continents, from Asia to Africa, from Australia to USA are also of help for additional contacts for infiltrating global markets 
(Buğra and Savaşkan. 2010). In these schools the instruction language is Turkish along with English and the curriculum familiarizes students with Turkish culture.

A widely shared common idea about the role of the religion in Turkey is that it functions as a basis for the generation of a closed and defensive world conception. Consequently, religion has long been conceived as the main theme of a polarization between a modern attitude and a conservative posture (Mardin, 2004: 82). Nevertheless, recent studies expose a series of data asserting that religion in Turkey does not only coalesce with a self-protectionist antimodernism, but rather it furnishes instruments to a personal inner guide-line through a rapidly changing society and facilitates the integration in a world of global fluencies (Göle, 1991; 2000). In the last decade, it appears that religious movements in Turkey have started to manifest themselves within civil society organizations mostly and separated from the strict ideology of political Islam (Y1lmaz, 2005). Especially, the religiously rooted business associations managed to produce a secularized discourse. For instance, TUSKON linked with the Gulen movement is an appropriate example of this new discourse. They put great emphasis on the secular premises of business rather than making Islamic values so evident. Exploring the impact of this newly emerging religious middle class on business world may also bring a new perspective to our understanding of network theory.

Turkey provides a rich context in which elites can be studied in the process of social, economic and political changes. Evidence of differences between new and old elites allows for an understanding of how elites change or struggle to retain their elite status. Therefore, the study here provides insights into new and old elites struggles towards becoming and remaining elite in the corporate world respectively. 


\section{Methodology}

Drawing upon the view that "elites are those groups that hold or exercise domination within a society or within a particular area of life" (Scott, 2008:32) we have defined business elites as the leading executive figures (such as chairperson, vice chairperson and CEO) of the holding companies whose affiliates are listed among the largest 500 companies in Turkey. This definition is also consistent with previous studies which perceive corporate elite as "a configuration of capitalists (major shareholders and top executives) and organic intellectuals occupying positions of ultimate authority within leading corporations" (Carroll, 2008:47).

The sample of the study was drawn from the owners and the managers of the largest Turkish companies for a larger study on elites in 2009-2011. A sub sample of 36 interviews is used for the present analysis. Elite networks are assessed through the membership to the largest businesspeople associations in Turkey namely. TUSIAD, MUSIAD and TUSKON. The data concerning businesspeople associations are gathered both through interviews and secondary information sources. This is an exploratory study which consists of a research design involving the exploration of a research topic or theory rather than being a test of it (Myers, 2009:23). Discourse analysis is conducted to analyze the data.

TABLE 1 ABOUT HERE

\section{Findings and Discussions}


Given the multidisciplinary nature of the work, we draw on the theories from sociology, political science and management. Thus, using elite theories (Carroll, 2008; Scott, 2008), and social network perspectives, we unveil the relationship between the context and elite networks. Theoretical abstraction presents a middle-range model concerning the formation and the functions of existing and emerging networks in Turkish business system. Different business networks (in the form of businesspeople's associations) accomplish specific functions, with sometimes complementing and mostly conflicting interests. Nevertheless, business associations are subject to the same contextual forces such as the world economy, dynamics of international relations, and political setting, crises and social movements, as well as ideologically-driven trends at the national level at the same historical moment. Yet, each business association is at a different stage of organizational evolution: while the long established one is at the peak of its integration with the global market and is sufficiently mature, the new one is in the phase of growth as it takes effectives steps to be more active in global market. Table 1 displays differences between TUSIAD, MUSIAD and TUSKON in relation to their level of development at international and national scale.

We provide a three layered framework through which we examine business networks in terms of their form and content in the global, national and association level relationships in the conclusion section of this paper. We also elaborate how these layers of relationships interplay with each other. Macro-Global aspects of business network relations

The business associations are about domination which leads to an exclusion of those who do not culturally conform and they generate a feeling of incompatibility on the part of those who hit the barrier of the domination (Authors, 2011). Consequently, a new network defining itself 'other' than the one preceding it, emerges as sufficient need is condensed around a 
motivational force towards global market. This being 'other' is not only explicitly encoded in cultural assets but also in specific needs such as integration with the global and national economy as experienced by this specific group of businesspersons.

Different networks meet on the aims of an economic mutuality for a growing business and global integration. This is how we can explain the synchronic existence of a series of networks, diverging culturally or ideologically, but completing thus an evolutionary landscape of the business world. As mentioned above these businesspeople networks differ in the type and level of their needs. TUSIAD members are big players and they are well connected with the rest of the world. They have mostly western cultural references. Several of them have led major international associations in their business field. They also appear to be members of the major international NGOs in their sector.

"I was elected as the chair of the World X Manufacturers Association for two years". (Chairman of a large industrial group).

Interesting to note that there was no affiliation of international associations among MUSIAD and TUSKON members. There is lack of integration with global networks MUSIAD/TUSKON members seem to be less familiar with the foreign markets and cultures. In contrast to TUSIAD members who have experienced foreign collaborations even before the economic liberalization, the newcomers like MUSIAD and TUSKON members have mostly appeared in the largest companies list or grew after the policy change in 1980. Being new in both national and international markets appears as a constraining factor especially in international business. However, especially in the case of TUSKON this is being overcome thanks to the schools of Gülen all over the world (Buğra and Savaşkan, 2010) which are attended, especially in less developed countries, by the children of local elites. In fact, with 
a careful examination of the web page of TUSKON it is observed that international relations with potential trade partners are created and maintained by the activities of this association. Therefore, TUSKON as a community functions as an international network provider. Thus, its members do not act individually in the international arena but they rather get introduced to international markets through community based activities offered to each member.

"TUSKON performs great internationally" (Chairman of a manufacturing companyTUSKON member).

Since the business contracts are assured through collective business trips to or from a country that are organized by TUSKON, participants reported similar investments in some countries, for example Brasil, among TUSKON members. On the other hand, TUSIAD members enjoy the benefits of being the members of an old association integrated with the world. Their "establishedness," experience, economic size provide the necessary means to conduct business through the community (TUSIAD) and individually.

"I have many partnerships. Many people cannot get along with westerners but I work very well with them. I have a partnership with the major player in the sector in Germany. (...) This year, I have also been appointed to the International Communication Committee at TUSIAD (Chairman of a large group. TUSIAD member).

TUSIAD members did not only establish individual trade partnerships but they also acted as leaders in promoting trade relations with specific countries. Their efforts were also recognized by different states. 
"I have been awarded by the Royal Order of Merit of Spain by the King for promoting trade relations between the two countries" (Chairman of a large group-TUSIAD member).

\section{Meso-National aspects of business network relations}

Business associations are also subject to the legacy of their foundation. We observe that the period of foundation, as in specific time and historical moment, institutes a different organizational habitus in each association. TUSIAD was established in 1971 in an unstable context characterized by social unrest and employer-employee conflicts, where social democrats and liberal conservatives used to compete for the government. TUSIAD was established to provide a network for the private sector rather than to represent the interests of business people (Buğra, 1998). Both MUSIAD and TUSKON emerged after 1980 where religious tone was remarkable in the discourse of the governments. Each network was established as a semi-reactionary movement towards the secular cultural codes represented by the older one.

Based on these perspectives, the present study investigates the inner dynamics of the Turkish business networks as well as the forces in the context contributing to their survival. The changing political and economic climate after 1980 facilitated the rise and growth of new networks. The rise of Islamic tendencies at the government level further encouraged new businesspeople networks which seemingly base their discourse on religion. This supportive 
environment was also reflected in the comments of the interviewees from MUSIAD/TUSKON.

During the crisis the president of the republic visited us and showed his emotional support" (Chairman, TUSKON member large industrial holding)

While he was proud of enjoying the support of the actual president, he was openly expressing his disappointment by the neglect of a previous president not close to Islamist tendency

"Even though I create employment and export a considerable part of my production, previous president [of the republic] never invited me to the presidential palace. However, the actual president invites." (Chairman, TUSKON member, large industrial holding)

The old elite businesspeople network, TUSIAD do not seem to benefit from the same level of political support in the 2000s. The discourse of the several of its members indicated a lack of support even a counteraction from government.

"The government wants to eradicate us" (CEO of TUSIAD member, large industrial holding)

It is also argued that the new religious business class is the reason for the emergence of AKP. In the post 1980 s political atmosphere, the affinity between politics and religious businesspeople appears to be their taste for liberal policies. In fact, our research focusing on the transformation of the economic elites' networks following the contextual shift delineates 
a significant change in the relative position of the religion among Turkish businesspeople. Despite the manifestation of nuanced attitudes, religion (the Islamic faith) in general seems to have become the primary common denominator in the new elites' networks.

\author{
"I am a TUSİAD member" \\ Interviewer: Are you a member of MUSİAD or TUSKON?" \\ "They are more politicized. TUSİAD is different. Since MUSIAD, etc have political \\ inclinations I would not like to be involved in. But I interact with all kind of groups in \\ Ankara." (Chairman of a group)
}

\begin{abstract}
According to the findings of our study, the newly emerging economic elites, who are mostly from a provincial-origin, adopt a more or less manifest religious attitude in their selfexpression and manners. Majority of MUSIAD/TUSKON members in our study state that they fully practice their religious beliefs. However, they are highly motivated for constituting business networks that aim integration with global liberal market, instead of preserving the reactionary conservative point of view.
\end{abstract}

"I am a faithful person. I fulfill all my religious duties, however, I am not fanatic. I would not mind for example going to a restaurant where alcohol is served. Or when I have a foreign client and we go for a dinner. He drinks alcoholic beverages at the same table. I would respect him. I have respect for every belief. I do not mind that he is Christian or Jewish or Armenian. I do have respect to all of them. Thanks God I am not fanatic." (...) I am not a member of TUSIAD. I do not share some of its views. TUSIAD is not democratic. But I am not against trading with them. (Chairman of large group). 
Networking is not always a strict adherence to a certain business association, with or without political connotation, but, for some of our interviewees, it is a question of developing a sufficiently diversified social capital, as a safeguard against contextual fluctuations.

"I do not have a membership in any association. However, my cousins, brothers [all partners in the same group] are members somewhere. My cousin is a member of TUSKON, my brothers are member of TUSIAD." (Chairman of a large group).

\section{Micro-association aspects of business network relations}

Every network is constituted of main components and the systematic cooperation evokes the establishment of (and around) a social capital, allowing in, those who share the same cultural codes (cultural capital) and exclude those who do not. Similarly those not sharing the same characteristics do not dare or want to become a part of the network. This was quite evident in the discourses of the businesspeople who did not join TUSIAD.

"TUSIAD is too big for us" (Chairman and CEO in a holding from Istanbul).

In fact, there are significant discrepancies between the economic, social and cultural capitals of the adherents of TUSIAD, MUSIAD and TUSKON in our sample. Given the overlaps between the MUSIAD and TUSKON members and the commonalities in their religious tone we preferred to put them together. Our findings show that TUSIAD membership is associated with the largest economic power. Its members in our sample are usually from companies whose sales exceeded 500 million or even 1 billion USD. The association with relatively smaller size companies is worth noting in the cases of MUSIAD and TUSKON members.

Quotes of the TUSIAD members often underline the size of their businesses: 
"We have the largest factory in the world in a single site." (CEO of a large group). Interesting to note that they tend to express the size of their companies in comparison to global or European scale. They make explicit that they are able to compete in global markets. They also express their economic capital in terms of their international market share:

"We are the largest $3^{\text {rd }}$ in market share in Europe." (Chairman of a large industrial group)

The divergence between the respective cultural capitals of these different networks' members is also considerable. TUSIAD members appear to have an undergraduate degree often from a university in USA or UK. They are also likely to have a graduate degree. The majority of TUSIAD members are also graduates of prestigious high schools where the instruction language is a foreign language. This is consistent with the fact that majority of this group seem to be able to speak more than one foreign language.

Among this group, there seems to be a trend about collecting paintings and (to a much lower degree) antiquities as well as establishing private universities or museums bearing the name of the family. They have western tastes.

"My interest is highest for plastic arts. (...) I visit art exhibitions, select artworks in national and international biennales and art fairs. I have a great interest in [classical] music but unfortunately only as a spectator I do not play any instrument. I am also interested in literature (...) I practice two types of sports: First is the one I do regularly as eating, sleeping.(...) I have also favorite sports: I practice equitation since my childhood. My father introduced me to it. I do sailing since longtime. I 
played soccer (...). I like skiing." (Chairman of a large industrial group-TUSIAD member).

While similar discourses have often been observed among TUSIAD members, MUSIAD and TUSKON members mentioned different tastes. The latters are usually interested in more popular sports and music types.

"I walk three days per week in the health club of the X Hospital. (...) I listen to the Turkish traditional popular music. (...) I do not have any other relationship with art. (Chairman of a large industrial group- TUSKON member)

MUSIAD and TUSKON members in our sample seem to differ considerably from TUSIAD members along the cultural capitals. Large majority does not have an undergraduate degree and none a graduate degree. The distance of the university to the city of dwelling appears as a major problem causing this limited time in educational institutions. The expectation that the older son should work in the family business was another reason which prevented further studies.

TABLE 2 ABOUT HERE

However, it is also worth mentioning that the children of MUSIAD and TUSKON members seem to achieve better education levels. They have undergraduate degrees and some of them prefer US universities. Thus heirs have a better education record and are able to speak foreign languages. Half of the TUSKON members in our sample do not know any foreign language. Most of them seem to have spent little time abroad and only for business trips. When we 
evaluate the presence of elite tastes as defined by Bourdieu we see that such tastes are inexistent. For example, none of them collects paintings or antiquities in contrast to TUSIAD members. However, the trend of establishing universities is also observed among TUSKON members. They get together with similar others to create new universities usually for a "foundation" and get actively involved in the board of trustees. Their more collectivistic orientation is worth noting.

"My son is the head of the board of trustees in our university.

Whose university is that?

A foundation's. (Chairman of a group-TUSKON member)

They are usually proud of contributing to these joint efforts of creating new universities. However, although those are joint efforts they tend to emphasize their own contributions. For them this is clearly a symbolic capital through which they gain legitimacy and reputation.

"I have constructed a Business and Economics Faculty. Ten people, we have provided 4 trillion Turkish Liras (\$2.2 million). (Chairman of an industrial company-TUSKON member)

Significant differences are also observed along the social capital dimension among TUSIAD and MUSIAD/TUSKON members in our sample. The notion of social capital appears to be the underlying concept of Bourdieu's thinking on the phenomenon of domination (Bourdieu, 1979). He conceptualizes social capital as a sum of actual or potential resources deriving from the very fact of possessing a more or less institutionalized network of durable relationships. The latter are also shaped in a process of interconnaissance or interreconnaissance which means that the social capital implies an affiliation with a group which is not only a set of common features, but also a system of permanent and useful links 
(Bourdieu, 1980: 2). Social capital creating useful links display various characteristics for the businesspeople networks we analyzed. One of the dimensions we wanted to assess is the father profession. In the case of TUSIAD members, the father profession appears to be industrialist. On the other hand "merchant" or "craftsman" appears as the father profession for MUSIAD/TUSKON members in our sample. There is only one exception who is farmer. Another dimension to assess social capital is the city of birth. Interestingly, we see that more than half of the TUSIAD members in our sample were born in cities other than metropolitan areas. On the other hand, all the MUSIAD/TUSKON members in our sample were born in non-metropolitan areas.

\section{Interrelationships between macro, meso, and micro levels}

Given the findings of our study we develop a model which is composed of interconnected parts, akin to a network that involves parts tied together with needs and functions that necessitate a form of organization, based on the use of cultural signs and a shared habitus to nurture trust system which generates legitimacy, credibility, economic cooperation and ideology.

The existing metropolitan-origin established business networks display mundane and western-oriented cultural characteristics while the new formations rather use religious themes and the explicit conservative attitude as a kind of ingredient of articulation with the capitalist relations at the world scale. In other words, conservatism functions, in rapidly changing social-economic context of Turkey, as a protecting cocoon, a kind of anti-shock armor for the sufficiently motivated individual who desires to be integrated into the global market, but who does not dispose the necessary cultural equipment that should support the logic of 
competitiveness. This might also be one of the main reasons that frequently generates an inner debate between conservatives-Islamists on being or not hypocritical about religion (Vergin, 2000: 62). We think that from bottom up this is an inevitable conflict triggered by the social change and forms of adaptation shared by conservative strata.

In spite of such a distance towards the non-material aspect of the globalization, the apparently conservative economic elite seems to approach to the values relative to a pluralistic point of view, a remarkable tendency to moral tolerance, a systematic recognition of cultural differences, often intellectually supported through the traditional humanism that the references are found in the traditional humanism reminiscent of the Sufi philosophy of Rumi or other historical Anatolian half-mythic and thus flexible stance towards Islam since centuries. In fact, Turkish Islam has a traditional orientation towards the state which facilitated its pragmatic and flexible tone. In other words, because Turkish Islam, as represented by religious functionaries, has traditionally done the state's bidding, it accepted the secularist order without demur (Mango, 2006:56). This flexible stance is also visible in the discourses of the MUSIAD/TUSKON members:

“...I do practice my religion however I have many friends who do not. For example, I often go out with them for a dinner, they drink alcoholic beverages and I don't and I do not mind it. Everybody is free to do what he/she wishes." (Male, chairman in an Anatolian company).

This flexibility appears even when they sign up new members for the business associations. The president of a sub-federation of TUSKON states that: 
"We have one criterion when we sign up a new member; we don't look at the political view, nor ethnicity. What we are looking for is straight/honest business history of the man/woman. This is the only criterion. We have members from different political views (left or right wing political parties). We have "Alevis" (A Turkish Shia sect). We have Kurds as well”.

Interviewer: Isn't religiosity a criterion?

"No. As I told you, we have members consuming alcohol, or smoking. But I personally don't drink and smoke".

This trend may also be interpreted as yet another confirmation of the underlying attributes of a certain Volkislam, perpetuated by a series of mystical beliefs (Mardin, 1986: 114). However, what remains to be explored is the centrality of the different groups to power and influence that is in the networks in which they are located. There is a difference between being included and being supported.

\section{Conclusion}

We presented a three layered framework, which summarizes our findings on the form and content of new and old business networks, across macro, meso and micro levels (See Table 3). The table also elaborates on the interrelationship between these levels and explicates how we combine theorization of Granovetter with that of Bourdieu in order to account for continuity and change in business network relations in a dynamic political economy. Drawing on Granovetter, we illustrated how network relationships have changed and by mobilizing Bourdieu we showed that the emerging networks of elites did not only generate their own 
logics but also interfered with old elites in multiple ways, sustaining the logic of the elite field in the country.

Table 3: A layered framework for outlining the form and content of business networks

\begin{tabular}{|c|c|c|}
\hline Levels & TUSIAD & MUSIAD/TUSKON \\
\hline Macro-global & $\begin{array}{l}\text { Mature relationships based } \\
\text { on formal ties }\end{array}$ & $\begin{array}{l}\text { Emergent relationships with } \\
\text { innovative and informal ties }\end{array}$ \\
\hline Meso-national & $\begin{array}{l}\text { Strong relationships with the } \\
\text { state, which are recently } \\
\text { formed based on economic } \\
\text { interests }\end{array}$ & $\begin{array}{l}\text { Strong relationships with the } \\
\text { state, which are based on } \\
\text { shared religious and regional } \\
\text { affinities }\end{array}$ \\
\hline Micro-association & $\begin{array}{l}\text { Based on economic interests, } \\
\text { size of business, and a } \\
\text { reputation for being secular } \\
\text { and modernist }\end{array}$ & $\begin{array}{l}\text { Originally based on religious } \\
\text { and regional affinities. But } \\
\text { more recently wider } \\
\text { membership based on } \\
\text { economic interests }\end{array}$ \\
\hline $\begin{array}{l}\text { Interrelationship between } \\
\text { layers }\end{array}$ & $\begin{array}{l}\text { Struggle to retain its } \\
\text { traditional power and } \\
\text { influence on government, } \\
\text { through its economic } \\
\text { influence and by building } \\
\text { collaborations with state } \\
\text { supported enterprises }\end{array}$ & $\begin{array}{l}\text { Struggle to join the national } \\
\text { and global economic elite, } \\
\text { with new interest in } \\
\text { secularized discourse. }\end{array}$ \\
\hline Granovetter & Strong ties & Strong ties with the state, \\
\hline
\end{tabular}




\begin{tabular}{|l|l|l|l|}
\hline & $\begin{array}{l}\text { economy, weak ties with } \\
\text { religious networks }\end{array}$ & weak ties with the global \\
\hline Bourdieu & Old elite subject to new & New elite subject to old \\
contextual pressures and & contextual pressures and \\
different set of tastes and & different set of tastes and \\
capitals, which are subject to & capitals, which are subject to \\
change
\end{tabular}

While established metropolitan business elites adopt values directly linked to the globalliberal pluralistic ideology throughout a mostly western orientation in education and socialization, the newly emerging counterparts construct ties to the same economic rationale with the help of both the preservation of traditional seriousness, and the not-too-muchstabilized pluralism together with an implicit open-mindedness. It is observed that the degree of integration with the world-scale economic activities of the economic elites (exportation, distribution, provisory or permanent representation, production in foreign countries) enhances the capacity to develop global and liberal values. Nevertheless, in newly emerging Anatolian capital, this liberalism seems to realize itself as such, at least in most of the cases.

On the contrary, what constitutes the appearance (manifest discourse as well as physical aspects) is more or less decorated with the well-known attributes and symbols of the Islamic conservatism. This is just at that point that the actual conservatism serves to establish social ties with ideologically-driven businesspeople associations or networks. Yet, we should also consider that 'economic institutions do not emerge automatically in response to economic needs' and structurally embedded individuals seem to have a major effect in the formation of institutional relations. (Granovetter, 1992:7) These increased networks, in exchange, provide 
them with their high motivation for the global liberal market, additional tools for the continuation of a growing commercial activity, while maintaining their conservatism in scope. The latter leads to a certain valorization of the attitude of respect for religious matters without creating an explicit contradiction between them and the liberal mind.

In the context of this paper, it would make more sense if we examine the genealogies of the concept of "secular" which can be regarded as an unfolding of the essence of religion (Martin, 1978). Marcel Gauchet, a well-known French philosopher, argues that Western secularism can only be understood through the historicity of Christianity (Gauchet, 1997). Talal Asad goes even a step further and claims that every religion produces its own secularism (Asad, 1993). In his book, Formations of the Secular, Asad focuses on the roots of the concept, "the secular":

For at one time "the secular" was part of a theological discourse (saeculum). "Secularisation" (saecularisatio) at first denoted a legal transition from monastic life (regularis) to the life of canons (saecularis)--and then after the Reformation, it signified the transfer of ecclesiastical real property to laypersons, that is, to the "freeing" of property from church hands into the hands of private owners, thence into market circulation. (Asad, 2003:192).

This historical root of secularism also clarifies the understanding of "the secular" in the context that we are referring as one of the conclusion we made about the emergence of the religious business elites in Turkey. Since Islam has different historical background and dynamics (Metcalfe, 2007) the Christian roots of the secular have to be different than Muslim ones. In the context of the religious business people, this conclusion refers to the Muslim business people's transition towards a more rational and systematised way of doing business. 
The new Islamic discourse they have been producing can be regarded as signs of this secularisation.

To conclude, our findings show that national context matters (Leat and El-Kot, 2007) and that contextual transformation had its repercussions in both business elite characteristics and elite networks in Turkey. Our study also reveals the significance of emic framing of context and demography as most of the contextual issues are unique and idiosyncratic, rather than etic and formulaic (Tatli and Ozbilgin, 2012). Both in-group characteristics and needs and contextual trends seem to influence business people networks. The desire to dominate or the possibility of recognizing different groups is related to the fit between the social, cultural and economic capitals possessed by the group and the contextual forces. We should also consider variability within national culture (Keles and Aycan, 2011). Political context, in particular the interplay of religion, state, employers are ignored in the network theory, which assumes that context is fixed, and not relevant to such theorization. In the this paper, we show that we need to consider context more keenly as the institutional differences are often outcome of unique historical paths and we bring an assessment of power and context to Granovetter's theorization.

\section{References}

Asad, T. (1993). Genealogies of Religion-Disciplines and reasons of power in Christianity and Islam. London: The Johns Hopkins University Press.

Asad, T. (2003). Formation of the secular. California:Stanford University Press.

Biggart, N. W., \& Delbridge, R. (2004). Systems of Exchange. Academy of Management Review, 29, 1, 28-49. 
Bourdieu, P. (1979). La Distinction : Critique Sociale Du Jugement. Paris: Les Editions de Minuit.

Bourdieu, P. (1980). Le Capital Social. Actes de la Recherche en Sciences Sociales, 31, 2-3. Buğra, A. (1994). State and Business In Modern Turkey: A Comparative Study. Albany: SUNY Press.

Buğra, A. (1998). Class, Culture and State: An Analysis of Interest Representation by Two Turkish Business Associations. International Journal of Middle East Studies, 30, 521-539.

Buğra, A., \& Savaşkan, O. (2010). Yerel Sanayi ve Bugünün Türkiye'sinde Iş Dünyası. Toplum ve Bilim, 118, 92-123.

Burt, R. S. (2005). Brokerage and Closure: An Introduction to Social Capital. Oxford: Oxford University Press.

Carroll, W. K. (2008). The corporate elite and the transformation of finance capital: A view from Canada. In M. Savage \& K. Williams (Eds.), Remembering Elites (pp. 44-63). London: Blackwell.

Collings, D.G., Demirbag, M., Mellahi, K. \& Tatoglu, E. (2010). Strategic orientation, human resource management practices and organizational outcomes: evidence from Turkey, The International Journal of Human Resource Management, 21 (14), 2589-2613.

Ercek, M. (2006). HRMization in Turkey: expanding the rhetoric-reality debate in space and time. The International Journal of Human Resource Management, 17 (4), 648-672.

Gauchet, M. (1997). The Disenchantment of the World: A Political History of Religion. Princeton: Princeton University Press.

Göle, N. (1991). Modern Mahrem. Istanbul: Metis Yayınları.

Granovetter, M. (1973). The Strength of Weak Ties. American Journal of Sociology, 78, 6, $1360-1380$. 
Granovetter, M. (1983). The Strength of Weak Ties: A Network Theory Revisited. Sociological Theory, 1, 201-233.

Granovetter, M. (1985). Economic Action and Social Structure: The Problem of Embeddedness. American Journal of Sociology, 91, 3, 481-510.

Granovetter, M. (1992). Economic Institutions as Social Constructions: A Framework for Analysis. Acta Sociologica, 35, 3, 3-11.

Guillén, M. F. (2001). The Limits of Convergence: Globalization and Organizational Change in Argentina, South Korea, and Spain. Princeton: Princeton University Press.

Gurbuz, S. \& Mert, I.S. (2011). Impact of the strategic human resource management on organizational performance: evidence from Turkey. The International Journal of Human Resource Management, 22(8), 1803-1822.

Kaya, N. (2006). The impact of human resource management practices and corporate entrepreneurship on firm performance: evidence from Turkish firms. The International Journal of Human Resource Management, 17(12), 2074-2090.

Kaya, N., Koc, E. \& Topcu, D. (2010). An exploratory analysis of the influence of human resource management activities and organizational climate on job satisfaction in Turkish banks. The International Journal of Human Resource Management, 21(11), 2031-2051.

Keles, S. \& Aycan, Z. (2011). The relationship of managerial values and assumptions with performance management in Turkey: understanding within culture variability. The International Journal of Human Resource Management, 22 (15), 3080-3096.

Keyman, F., \& Lorasdağı, B. K. (2010). Kentler-Anadolu'nun Dönüşümü, Türkiye’nin Geleceği. İstanbul: Doğan.

Kumbaracıbaşı, A. C. (2009). Turkish Politics and the Rise of The AKP-Dilemmas Of Institutionalization And Leadership Strategy. NY: Routledge. 
Kusku, F. \& Ataman, B.M. (2011). Employement interview satisfaction of applicants within the context of a developing country: the case of Turkey. The International Journal of Human Resource Management, 22(11), 2463-2483.

Lacinok, N. (2007). “Turgut Özal” Türk Dış Politikasında Liderler. In A. F. Demir (Ed.), (pp. 537-639). Istanbul: Bağlam.

La Porta, R., Lopez-De-Silanes, F., \& Shleifer, A. (2008). The Economic Consequences of Legal Origin. Journal of Economic Literature, 46, 2, 285-332.

Leat, M. \& El-Kot, G. (2007). HRM practices in Egypt: the influence of national context? The International Journal of Human Resource Management, 18 (1), 147-158.

Lounsbury, M., \& Ventresca, M. (2003). The New Structuralism in Organizational Theory. Organization, 10, 3, 457-480.

Mango, A. (2006). Religion and Culture in Turkey. Middle Eastern Studies, 42,6, 997-1032.

Mardin, Ş. (1986). Din ve İdeoloji. İstanbul: İletişim Yayınları.

Mardin, Ş. (2004). Türkiye'de Din ve Siyaset. İstanbul: İletişim Yayınları.

Martin, D. (1978). A General Theory of Secularization, Oxford: Basil Blackwell.

Metcalfe, B. D. (2007). Gender and human resource management in the Middle East. The International Journal of Human Resource Management, 18 (1), 54-74.

Myers, M. D. (2009). Qualitative Research in Business and Management, London: Sage.

Öniş, Z., \& Türem, U. (2001). Business, Globalization and Democracy: A Comparative Analysis of Turkish Business Associations. Turkish Studies, 2, 94-120.

Öniş, Z. (2004). Turgut Özal And his Economic Legacy: Turkish Neo-Liberalism In Critical Perspective. Middle Eastern Studies, 40, 4, 113-134.

Pamuk, Ş. (2008). Globalization, Industrialization and Changing Politics in Turkey. New perspectives on Turkey, 267-273. 
Pettigrew A. (1992). On Studying Managerial Elites. Strategic Management Journal, 13, 163-182.

Savage, M., \& Williams, K. (2008). Elites: Remembered In Capitalism and Forgotten by Social Sciences. In M. Savage, \& K. Williams (Eds.), Remembering Elites (pp.1-24). London: Blackwell.

Scott, J. (2008). Taking Stock of Elites: Recognizing Historical Changes. In M. Savage, \& K. Williams (Eds.), Remembering Elites (pp. 27-43). London: Blackwell.

Sönmez, M. (2010). Türkiye'de Iş Dünyasının Örgütleri ve Yönelimleri, Istanbul:Friedrich Ebert Stiftung Derneği.

Townley, B. (2002). Managing With Modernity. Organization, 9, 4, 549-573.

Türe, F. (2008). Devlet: Liberalizmin Bir Serüveni. In R. Gönlü (Ed.), Devlet ve Sermayenin Yeni Biçimleri (pp. 73-93). Ankara: Dipnot Yayınları.

Vergin, N. (2000). Din, Toplum ve Siyasal Sistem. İstanbul: Bağlam Yayınları.

Whittington, R. (2004). Strategy After Modernism. European Management Review, 62-68.

Y1lmaz, I. (2005). State, Law, Civil Society and Islam in Contemporary Turkey. The Muslim World, 95, 3, 385-411.

Yurtoglu, B. B.(2000). Ownership, Control and Performance of Turkish Listed Firms. Empirica, 27, 193-222.

Yurtoglu, B. B. (2004). Persistence of Firm-Level Profitability In Turkey. Applied Economics, 36, 615-625.

Zald, M.N. \& Lounsbury, M. (2010) The wizards of Oz: Towards an Institutional Approach to Elites, Expertise and Command Posts. Organization Studies,31, 963-996. 
Table 1. Businesspeople Associations

\begin{tabular}{|c|c|c|c|c|c|c|c|}
\hline Name & $\begin{array}{l}\text { Establishe } \\
\quad \mathrm{d} \text { in }\end{array}$ & $\begin{array}{c}\text { Headquarters } \\
\text { at }\end{array}$ & $\begin{array}{c}\text { Foreign } \\
\text { memberships }\end{array}$ & $\begin{array}{c}\text { Affiliated } \\
\text { associations }\end{array}$ & $\begin{array}{c}\text { Foreign } \\
\text { representatives }\end{array}$ & Values & $\begin{array}{c}\text { Economic } \\
\text { representation }\end{array}$ \\
\hline TÜSİAD & $\begin{array}{c}1971 \\
\text { President: } \\
\text { N.Ümit } \\
\text { Boyner (F) } \\
1963 \\
\text { RC+ } \\
\text { University } \\
\text { of } \\
\text { Rochester } \\
\text { Econ. } \\
\text { Financial } \\
\text { manager }\end{array}$ & \begin{tabular}{|l} 
Istanbul \\
Governing \\
Board \\
General \\
Assembly \\
High \\
Consulate \\
Council \\
[Former \\
presidents of \\
TUSIAD + \\
Former high \\
bureaucrats] \\
\\
5 female \\
members \\
among 21 \\
board \\
members \\
\\
2 female \\
presidents
\end{tabular} & $\begin{array}{l}\text { Business } \\
\text { Europe } \\
\text { Businessmed } \\
\text { UBCGE } \\
\text { (Black } \\
\text { sea\&Caspian) }\end{array}$ & $\begin{array}{l}\text { Local } \\
\text { businessmen } \\
\text { associations } \\
\text { with a-SİAD } \\
\text { suffix } \\
\text { All Young- } \\
\text { SİADs }\end{array}$ & $\begin{array}{l}\text { TÜSİAD Berlin } \\
\text { Branch } \\
\text { TÜSİAD Beijing } \\
\text { Branch } \\
\text { TÜSİAD Paris } \\
\text { Branch } \\
\text { TÜSİAD } \\
\text { Washington Rep. } \\
\text { TÜSİAD EU } \\
\text { Brussels Rep. }\end{array}$ & $\begin{array}{l}\text { Productivity } \\
\text { Sustainable } \\
\text { economic } \\
\text { growth } \\
\text { Liberal } \\
\text { economy } \\
\text { Democratic } \\
\text { standards } \\
\text { Human rights } \\
\text { Integration to } \\
\text { EU } \\
\text { Secular }\end{array}$ & $\begin{array}{l}\text { Members in industry } \\
\text { and services sectors: } \\
85 \% \text { of corporate } \\
\text { taxes } \\
65 \% \text { foreign trade } \\
\text { (energy sector not } \\
\text { included) } \\
65 \% \text { industrial } \\
\text { production } 50 \% \text { of } \\
\text { added value } \\
50 \% \text { of registered } \\
\text { employment } \\
\text { In } 2009,142 \\
\text { member companies } \\
\text { were in the largest } \\
500 \text { list. }\end{array}$ \\
\hline
\end{tabular}




\begin{tabular}{|c|c|c|c|c|c|c|}
\hline MÜSİAD & $\begin{array}{c}1991 \\
\text { President: } \\
\text { O.Cahit } \\
\text { Vardan } \\
\text { (M) } \\
1962 \\
\text { ITU+Ohio } \\
\text { State } \\
\text { Ind.Eng. } \\
\text { Businessm } \\
\text { an }\end{array}$ & $\begin{array}{l}\text { Istanbul } \\
\text { Governing } \\
\text { Board } \\
\text { General } \\
\text { Assembly } \\
\text { High } \\
\text { Consulate } \\
\text { Council (no } \\
\text { info) } \\
\text { No female } \\
\text { among } 21 \\
\text { board member }\end{array}$ & $\begin{array}{l}\text { İSHAD } \\
3100 \text { members } \\
\text { in } 33 \text { branches } \\
4700 \text { members } \\
\text { of which } 1650 \\
\text { are Young- } \\
\text { MUSIAD } \\
15000 \text { firms }\end{array}$ & $\begin{array}{l}92 \text { liaison offices } \\
\text { in } 43 \text { countries }\end{array}$ & $\begin{array}{l}\text { "National } \\
\text { Perspective" } \\
\text { (Highly } \\
\text { religious } \\
\text { tendency } \\
\text { favoring an } \\
\text { industrial-basis } \\
\text { development for } \\
\text { an independent } \\
\text { national context) } \\
\text { Self } \\
\text { development as } \\
\text { well as national } \\
\text { progress }\end{array}$ & $\begin{array}{l}\$ 3 \text { bn./year of } \\
\text { investment } \\
\$ 90 \text { bn. of GNP } \\
(15 \%) ; \\
15 \% \text { of employment } \\
17 \% \text { of foreign trade } \\
\text { Small and middle } \\
\text { size firms } \\
\text { In } 2010,31 \text { member } \\
\text { companies were in } \\
\text { the largest } 500 \text { list. }\end{array}$ \\
\hline TUSKON & $\begin{array}{c}2005 \\
\text { President: } \\
\text { Riza Nur } \\
\text { Meral } \\
\text { (M) } \\
1958 \\
\text { METU Ind } \\
\text { Eng. } \\
\text { Top } \\
\text { manager }\end{array}$ & $\begin{array}{l}\text { Istanbul } \\
\text { Board of } \\
\text { directors } \\
\text { Supervisory } \\
\text { board } \\
\text { Board of } \\
\text { regulations } \\
\text { General } \\
\text { Assembly } \\
2 \text { female out } \\
\text { of } 42 \text { board } \\
\text { directors } \\
\text { No female } \\
\text { presidents }\end{array}$ & $\begin{array}{l}\text { TİM member } \\
\text { Federations: } 7 \\
\text { regional } \\
\text { business } \\
\text { federations } \\
\text { Associations: } \\
160 \\
\text { businessmen } \\
\text { associations in } \\
80 \text { districts }\end{array}$ & $\begin{array}{l}\text { Brussels } \\
\text { Beijing } \\
\text { Moscow } \\
\text { Washington }\end{array}$ & $\begin{array}{l}\text { Conservative } \\
\text { Pragmatist } \\
\text { Pro-Fethullah } \\
\text { Gülen } \\
\text { Community } \\
\text { [Influential } \\
\text { religious } \\
\text { solidarity group] } \\
\text { Self interest } \\
\text { oriented }\end{array}$ & $\begin{array}{l}25000 \text { businessman } \\
\text { and entrepreneur } \\
\text { members } \\
624 \text { firms } \\
\text { Small and middle } \\
\text { size firms } \\
\text { Growing companies } \\
\text { In } 2010,92 \text { member } \\
\text { companies in the } \\
\text { largest } 500 \text { list. }\end{array}$ \\
\hline
\end{tabular}

Source: Collected from documents provided by TÜSIAD, MÜSIAD and TUSKON and their respective websites. 
Table 2: Business Associations and Individual Characteristics of Their Members

\begin{tabular}{|c|c|c|c|c|}
\hline Name & $\begin{array}{l}\text { Economic } \\
\text { capital }\end{array}$ & $\begin{array}{l}\text { Cultural capital } \\
\text { Education }\end{array}$ & $\begin{array}{c}\text { Cultural capital } \\
\text { Tastes }\end{array}$ & $\begin{array}{l}\text { Social capital } \\
\text { Family }\end{array}$ \\
\hline TÜSİAD & $\begin{array}{l}>500 \text { million }-1 \\
\text { billion USD } \\
\text { Mostly large } \\
\text { companies }\end{array}$ & $\begin{array}{l}\text {-Undergraduate degree often from a } \\
\text { university in USA or UK. } \\
\text {-Likely to have a graduate degree. } \\
\text {-Often graduates of prestigious high } \\
\text { schools where the instruction language is a } \\
\text { foreign language. } \\
\text {-Majority is able to speak more than one } \\
\text { foreign language. Most of them have spent } \\
\text { at least one year abroad. }\end{array}$ & $\begin{array}{l}\text {-Trend about collecting paintings and } \\
\text { (to a much lower degree) antiquities } \\
\text { as well. } \\
\text {-Trend of establishing private } \\
\text { universities bearing the name of the } \\
\text { family. }\end{array}$ & $\begin{array}{l}\text {-Father profession industrialist } \\
\text {-Half from non-metropolitan areas }\end{array}$ \\
\hline $\begin{array}{l}\text { MÜSİAD- } \\
\text { TUSKON }\end{array}$ & $\begin{array}{l}\text { Mostly small } \\
\text { and medium } \\
\text { sized companies }\end{array}$ & $\begin{array}{l}\text {-Large majority does not have an } \\
\text { undergraduate degree } \\
\text {-None with a graduate degree. (The } \\
\text { distance of the university to the city of } \\
\text { dwelling appears as a major problem } \\
\text { causing this limited time in educational } \\
\text { institutions). } \\
\text { - Half of the TUSKON members in our } \\
\text { sample do not know any foreign language. } \\
\text { Most of them seem to have spent little time } \\
\text { abroad and only for business trips. }\end{array}$ & $\begin{array}{l}\text {-No collectors } \\
\text {-Trend of getting together with } \\
\text { similar others to create new } \\
\text { universities usually for a } \\
\text { "foundation" and getting actively } \\
\text { involved in the board of trustees. }\end{array}$ & $\begin{array}{l}\text {-Father profession merchant or } \\
\text { craftsman } \\
\text {-All of them from non-metropolitan } \\
\text { areas }\end{array}$ \\
\hline
\end{tabular}

